\title{
Dealing with Climate Change: Concerns and Options
}

\author{
Pooja Arora ${ }^{1}$, Smita Chaudhry ${ }^{2}$ \\ Institute of Environmental Studies, Kurukshetra University, Kurukshetra, Haryana-136119, India
}

\begin{abstract}
Changes have occurred in the composition of greenhouse gases in the lower atmosphere during the last century primarily from the burning of fossil fuels and deforestation in tropical regions. Climate change is posing great threat to wildife and protected areas by modifying habitats and increasing the prevalence of threats such as fire, pests and pathogens. Therefore, a climate change assessment is necessary to cope up with the adversities due to climate change. It has been suggested that forest action can cost effectively provide around $30 \%$ of the total effort needed in all sectors to meet climate mitigation strategies. Plantation programs can be used to create carbon credits to generate significant income for developing countries. The other most familiar ways to reduce GHG emissions are increasing energy efficiency and using alternative energy sources. In Indian context, the undervaluation of forests is causing immense losses to the forestry sector and overall economic system. The implementation of REDD+ and CDM framework could provide an opportunity to create and secure economic funds management, conservation and restoration of forests for mitigating climate change. The concept of Joint Forest Management and social forestry based on principals of community forestry has also gained a widespread significance in managing forests over the entire nation. The possibilities for mitigation in India also lie in the renewable energy sector along with industrial sector with improved energy efficiency. Integrated measures and effort at all international, national and regional are needed to fight against the changing climate.
\end{abstract}

Keywords: Climate Change, Forest Management, IPCC, Carbon sequestration, Mitigation, Energy Efficiency, REDD+

\section{Introduction}

Climate changes continuously as the components of the climate system interact non-linearly at very different time scales from the minutes to billion years. Conventionally, 30year intervals have been used for calculating averages and estimating weather variables. However, natural climate varies on time scales from year to year, through decades to decades to longer term fluctuations over centuries and millennia.

Over the 20th century there has been a significant increase in GHGs in the atmosphere due to human activities such as fossil fuel burning and land use change. The ,enhanced greenhouse effect ${ }^{\mathrm{ee}}$ and resulting global climate change is posing great threat to the well-being of humans, increasing pressure on wildlife and protected areas by modifying habitats and increasing the prevalence of threats such as fire, pests and pathogens.

Current projections of climate change constitute a further increase in average global surface temperature $\left(1.8-4^{\circ} \mathrm{C}\right.$ change by 2090-2099) and atmospheric carbon dioxide concentrations, changes in precipitation as well as altered disturbance regimes under different scenarios [1]. The globally averaged combined land and ocean surface temperature data as calculated by a linear trend, show a warming of 0.85 [0.65 to $1.06{ }^{\circ} \mathrm{C}$, over the period 1880 to 2012 , based on multiple independently produced datasets [2]. The atmospheric concentrations of the greenhouse gases carbon dioxide $\left(\mathrm{CO}_{2}\right)$, methane $\left(\mathrm{CH}_{4}\right)$, and nitrous oxide $\left(\mathrm{N}_{2} \mathrm{O}\right)$ have increased since 1750 due to human activity. In 2011 the concentrations of these greenhouse gases were estimated to be $391 \mathrm{ppm}, 1803 \mathrm{ppb}$, and $324 \mathrm{ppb}$, and exceeded the pre-industrial levels by about $40 \%, 150 \%$, and $20 \%$, respectively [2]. Since 1870 , even the global sea level has risen by about 8 inches [3]
Many different scenarios are developed and used by entire world research community to improve understanding of the complex interactions of the climate system, ecosystems, and human activities with a goal to better understand uncertainties under a wide range of possible futures in order to reach decisions.

\section{Dealing with Climate Change}

It has been suggested that twenty percent of the $\mathrm{CO}_{2}$ being emitted today will still affect the earth "s climate 1,000 years from now [4]. So, assessments of climate change impacts on various sectors of the economy directly or indirectly are essential for devising approaches, strategies and action plans to respond to the changes. A comprehensive climate change assessment both at the national and state level is necessary for timely preparedness and response to minimize impacts and cope up with the adversities due to climate change [5]. The options, thus remaining for dealing with the crisis are to mitigate; to adapt and to suffer.

Mitigation involves doing things to reduce the pace and magnitude of the changes by using new technologies and renewable energies, making equipments more energy efficient, changing management practices and consumer behavior. Climate change mitigation requires the management of terrestrial carbon (C) either by creating new $\mathrm{C}$ sinks or by preserving existing ones [6]. Adaptation refers to adjustments in ecological, social, and economic systems by reducing the potential adverse impacts resulting from the by-products of climate change including constructing sea barriers, relocation of coastal towns and cities inland, changing agricultural practices according to shifting weather patterns, and strengthening human and animal immunity to climate-related diseases. Suffering, means enduring the adverse impacts that cannot be staved off by mitigation or adaptation [7]. Each biotic community, not only humans, 


\section{International Journal of Science and Research (IJSR) \\ ISSN (Online): 2319-7064}

Index Copernicus Value (2013): 6.14 | Impact Factor (2014): 5.611

will be affected by global warming. The communities living in or near ecologically sensitive areas will suffer the most.

While most efforts to set targets for warming emissions have focused on the UNFCCC, other regulatory treaties have a big impact on emissions of these gases. The industrialized countries that have ratified the Kyoto Protocol are required to achieve a significant emission reduction domestically which can be supplemented through three international market-based mechanisms [8, 9]:

- Joint Implementation (Article 6), whereby an industrialized country may acquire emission reduction units when it helps to finance projects that reduce emissions in another industrialized country (including economies in transition)

- The Clean Development Mechanism (CDM) (Article 12), which allows developing countries to achieve sustainable development by permitting industrialized countries to finance greenhouse gas reduction projects in developing countries and receive credit for doing so.

- International Emissions trading (Article 17), which provides for industrialized countries to acquire units from other countries and use them towards meeting their emission targets under the Kyoto Protocol. This enables the countries to make use of lower-cost opportunities to reduce emissions, irrespective of the country in which those opportunities exist.

The industrial sector is responsible for $1 / 3 \mathrm{rd}$ of global primary energy use and $2 / 5$ th of global energy related carbon dioxide emissions. Developing countries and transition economies account for $58 \%$ of total industrial energy use. China's share alone amounts to $23 \%$; Asia as a whole accounts for $35 \%$ while Africa accounts only for 3.1\% [10]. Thus, largest contribution to emissions reduction can be achieved through improving energy efficiency and switching to renewable energy. In context of improved energy efficiency, IPCC [11] analysis suggests that industry might be expected to save 15 to $30 \%$ of the total baseline emissions in 2030 .

Modern bio-energy can contribute substantially to mitigation by providing an alternate source of renewable energy. It has the potential to shift the geography of international energy markets and challenge the petroleum economy [12]. Bioenergy plantations can also lead to restoration of land, manage water runoff, retain soil carbon and benefit rural economies by providing employment and income

The Bali Action Plan in 2007, laid out a strategy for developing consensus on how to recognize reducing emissions from deforestation and degradation (REDD). This strategy represents an important component of a viable global climate policy framework which has captured international attention as a potentially effective and low-cost climate change mitigation option in developing countries $[11,13]$. REDD + mechanism can be viewed as a multi-level Payment for Ecosystem Scheme (PES) that works on International, National and Sub-national levels [14].

\section{Forest Management and Climate Change}

Climatic changes already have complex effects on the biophysical processes that underpin natural ecosystems, with positive and negative impacts and so reducing the atmospheric concentration of $\mathrm{CO}_{2}$ is becoming a target of global communities. Temperature increases may initially drive forest productivity [15], but as the projections go farther, productivity may tend to fall [16]. It may also be affected by seasonal climate variability in the long-term.

Forest loss, primarily tropical deforestation and forest degradation and emissions from land-use changes accounts for approximately 17-20 per cent of global greenhouse gas emissions [17]. Degradation of forest resources also has a detrimental effect on soil and water quality, human and animal life and also affects climate patterns. Therefore, forests are prominent sites to study of climate change, not only in terms of total net carbon emissions but also in terms of global storage capacity depending on their age, health and susceptibility to wildfires and other disturbances, as well as on how they are managed which is important for climatic regulation. The forest carbon stocks (biomass and soil carbon stocks) can be efficiently increased with strategic forest management practices.

Forest management is the process of planning and implementing practices for the stewardship and use of forests and other wooded land aimed at achieving specific environmental, economic, social and/or cultural objectives [18] while the evolving concept of Sustainable Forest Management aims to maintain and enhance the economic, social and environmental value of all types of forests, for the benefit of present and future generations (UN Resolution $62 / 98)$

The Intergovernmental Panel for Climate Change (IPCC) estimates that about $65 \%$ of the total mitigation potential in the forest sector is located in the tropics and about $50 \%$ of this total could be achieved by reducing deforestation [19]. Many forestry practices with associated costs exist which can increase the carbon sequestration on forest land like:

- Afforestation of agriculture land;

- Reforestation of harvested or burned timberland;

- Lengthening forest rotation cycles;

- Preservation of forestland from conversion;

- Adoption of agroforestry practices;

- Establishment of short-rotation woody biomass plantations;

- Urban forestry practices.

It has been suggested that 2000 million ton of carbon sequestration is possible in the cost range of $\$ 10$ to $\$ 150$ per ton of carbon [20].

According to a study of Sohngen [21], a typical hardwood forest may contain 257 ton $\mathrm{CO}_{2}$ per hectare in aboveground carbon that would have a return of $\$ 30-\$ 40$ per hectare per year. At a carbon price of $\$ 14$ per ton of $\mathrm{CO}_{2}$, the annual return from this amount of stored carbon comes out to be around $\$ 75-\$ 80$ per hectare per year. If carbon prices are doubled, means at a rate of $\$ 28$ per ton of $\mathrm{CO}_{2}$, the annual 


\section{International Journal of Science and Research (IJSR) \\ ISSN (Online): 2319-7064 \\ Index Copernicus Value (2013): 6.14 | Impact Factor (2014): 5.611}

returns for that particular forest land will come out to be around $\$ 130-\$ 140$ per hectare per year (Figure 1). Also, if a ton of emitted $\mathrm{C}$ has a price of $\$ 10$, the calculated value of incremental soil $\mathrm{C}$ sequestration would be at $\$ 17.90$ per hectare per year [22]. This increase in return from the forest land when embodied carbon is valued makes the forest highly competitive with other agricultural and grazing lands.

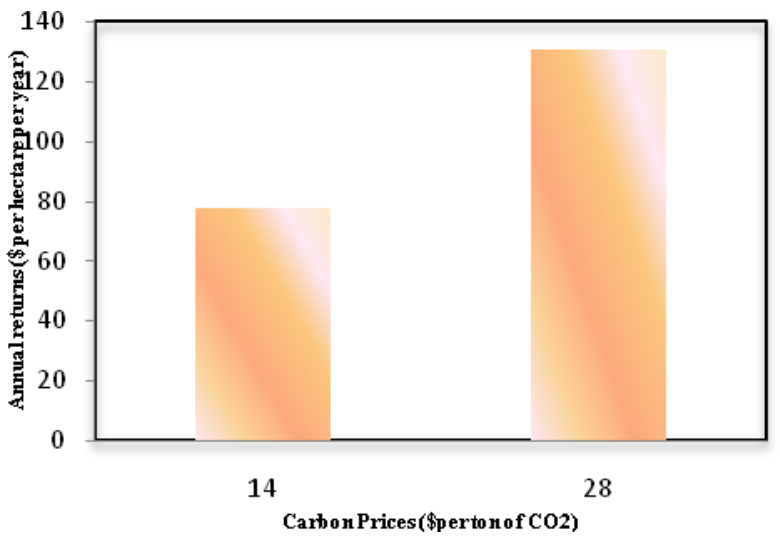

Figure 1: Annual returns of hardwood forest inclusive of timber harvests

Forestry has also been recognized by the Kyoto Protocol as a sink measure for greenhouse gases in the atmosphere under the Clean Development Mechanism (CDM) in terms of afforestation and reforestation. Forests generating carbon credits are often influenced by deforestation and degradation. The drivers for forest destruction are (a) Commercially planned logging; (b) Illegal logging; (c) Agricultural plantation development; (d) Small-scale subsistence activities; (e) Urban development; (f) Ranching; (g) Conversion of natural forest to industrial tree plantations; (h) Rural development; (i) Oil and gas exploration and (j) mining (Figure, 2) [23]. Hence, reviving forest cover and finding low cost methods to sequester carbon can be viewed as a major international policy aim.

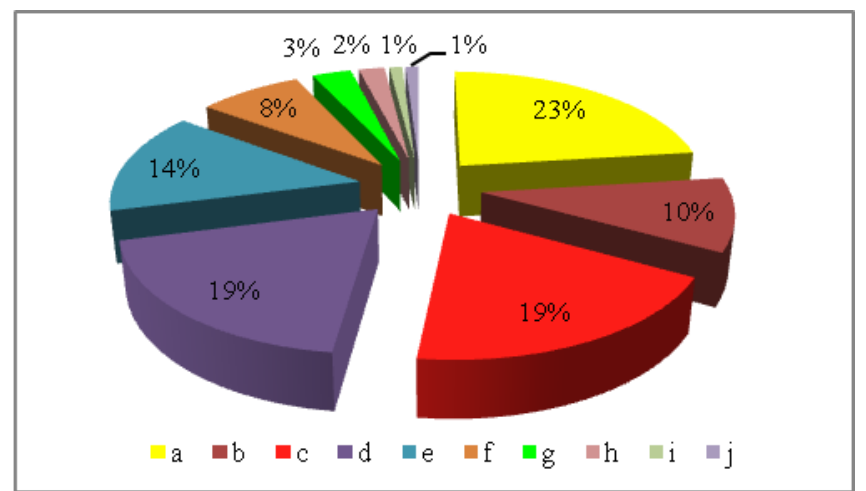

Figure 2: Drivers of Forest Destruction and their percent contribution

Actual forest management decisions are never made under conditions of certainty. There always exist some risks due to weather, mortality, stock, insects, disease, fire, stumpage price fluctuations and many other factors [24] that are supposed to be well managed to have successful outcomes. Risk management in forestry decisions was suggested by Hool [25] using a Markovian framework to analyze the management of even-aged plantations. It is also well known that the mixed species plantation has more advantages than single stands and could reduce the disadvantages of production, climate adversities and market risks. Tree plantations depending on verifiable methods to the biomass stocks and carbon sequestration rates can be used to create carbon credits for generating significant income for developing countries.

Land-use changes are also the important determinants for the carbon management. Appropriate understanding of the transitions resulting from land-use changes such as nutrient deposition and direct changes like silviculture can accurately predict carbon management benefits in any ecosystem. These changes potentially influence the amount of biomass and carbon stocks of vegetation and soil.

The already low concentration of organic matter concentration, in the tropical soils $(<1.0 \%)$, would become still lower in changing climatic regimes which will also lead to the changes in soil biology and microbial populations. Depletion and degradation in amount and quality of the SOC pools has adverse long term effects on productivity. Soil contributes about $20 \%$ to the total emission of carbon dioxide through soil respiration and root respiration, $12 \%$ of methane and $60 \%$ of anthropogenic nitrous oxide emissions [26]. Sustaining soil organic carbon (SOC) is thus, of prime importance in terms of cycling the plant nutrients and improving its physical, chemical and biological properties [27] and thereby reversing the impacts of land degradation and desertification.

Many of the ecosystem services do not possess explicit market prices as they are supposed to be freely available to all; however, the absence of a market price should not mean that these services are without any value. Payments for ecosystem services may prove to be useful in preserving, acknowledging and rewarding good community forest management practices. Active participation of communities in all aspects of forest management, taking into account people"s needs, aspirations, rights, skills and knowledge can significantly contribute to the efficiency, sustainability and equity of forest-based measures to tackle the problem of climate change [28]. Adaptation strategies that promote sustainable and community based forest management have the potential to protect land and people from harmful effects of rising global temperatures, provide opportunities, sustainable rural development and poverty alleviation through income generation and employment opportunities [29]. Hence, biological carbon sequestration projects can prove to be mutually beneficial for environmental conservation and generating opportunities for economic development in poor countries.

\section{India and Climate Change}

India emitted 1,728 million tonnes $\mathrm{CO}_{2}$ equivalent of greenhouse gases as per the estimates of NATCOM, 2007, making it the sixth largest emitter of greenhouse gases in the world [30]. The impacts of climate change are uncertain but there is strong indication that melting of glaciers in the Himalayas will impact the countryes hydrological potential. India will be affected by "increasing variability of already highly variable rainfall patterns" [31]. Being a party to the United Nations Framework Convention on Climate Change

\section{Volume 4 Issue 11, November 2015}




\section{International Journal of Science and Research (IJSR) \\ ISSN (Online): 2319-7064}

Index Copernicus Value (2013): 6.14 | Impact Factor (2014): 5.611

(UNFCCC), India attaches its great importance to climate change issues. Under the Copenhagen Accord, India has pledged to reduce carbon intensity by 20 to $25 \%$ below 2005 levels by 2020 .

India is one of the countries which are predicted to be mostly exposed to climate change impacts. It has been estimated that up to $3 \%$ of its GDP is already spent annually responding to the adverse impacts of climate change. Being one of the fastest growing economies in the world, India is facing dual challenges of the need for rapid growth as well as escalating GHG emissions. At the national level, Government of India is implementing wide range of regulations and incentives to reduce emissions and is preparing adaptation plans. The country has developed many institutional arrangements concerning climate policy. The Prime Ministeres Council for Climate Change (PMCCC) was established in the year 2007. This Council achieved a landmark by releasing the National Action Plan on Climate Change (NAPCC) in 2008 forming the legal basis for climate policy in India. The Expert group on Low Carbon Strategy for inclusive Growth was established in 2009 which has published an interim report in 2011 and final report in 2014 concerning climate change and poverty eradication. The Indian Network on Climate Change Assessment (INCCA) established in the year 2009 is responsible for coordinating research institutions, inventory estimations and climate research. The 12th FYP for the period from 2013-2017, for the first time has a chapter dedicated to sustainable development, focusing on economic growth and sets a target GDP growth rate of $8.2 \%$ per year until 2017 to overcome poverty and to meet the millennium development goals [32].
The main possibilities for greenhouse gas (GHG) mitigation in India lie in the energy supply sector, specifically in the area of renewable energy along with the industry sector, which is subject to rapid changes due to increasing economic wealth [33]. The main barriers to renewable energy in India are lack of capacity and resources of governmental institutions, uncoordinated support policies [34], high financing costs for installation of RE, low labour costs, high interest rates and rapid decreases in costs of renewable energy technologies [35] compromising with standards and quality [34].

India is also known for its diverse forest ecosystems. These ecosystems are very critical for sustaining biodiversity, protecting watersheds, and livelihoods of many indigenous and rural communities. They possess significant ecological and economic values. Forests have been accounted only for their tangible products and services which include direct cash exchange. The non-cash, intangible or indirect use values are required to be thoroughly accounted for total economic valuation of the forest sector (Figure 3). This contribution can be further improved by improving the forest governance which has two facets:

a) To identify the changes those directly address gaps in efficient economic utilization of forest values through decision based on better information and evidence.

b) To identify the changes that aim at the long-term sustainability of both economic and other values from forests. This can be achieved through participation of constituents which are likely to be affected by policy decisions.
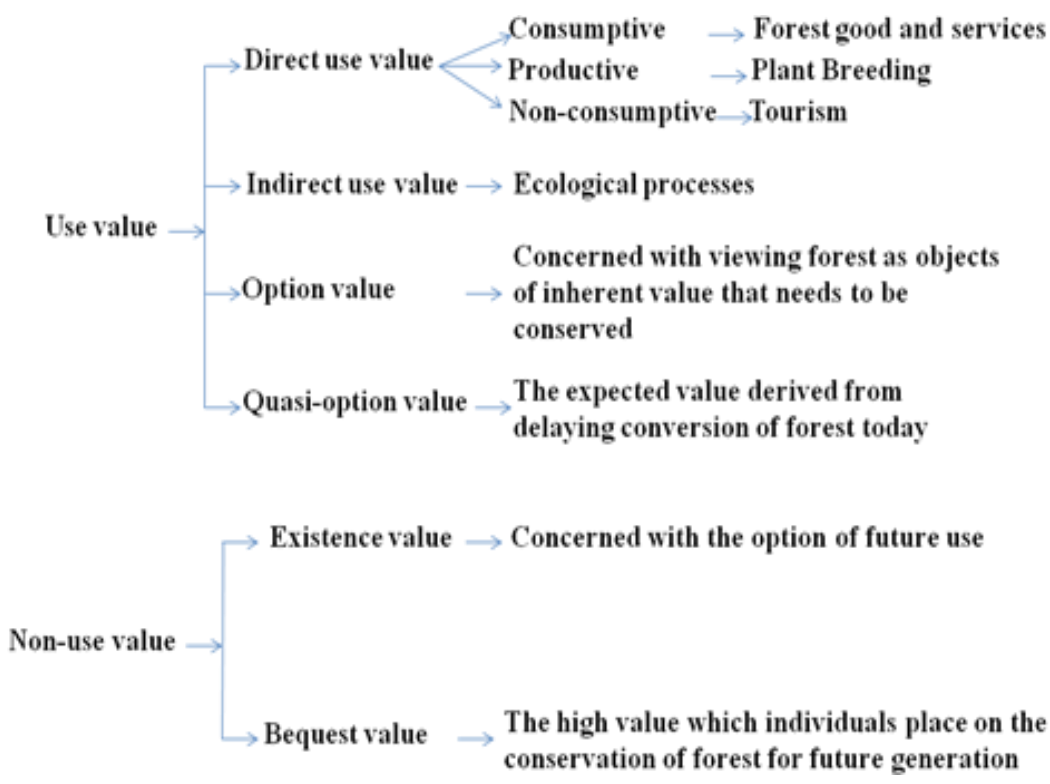

Figure 3: Total Economic Value of Forests

Although forests provide multiple benefits, the contribution of this sector to countryes GDP has been very low. In 199697 , the contribution of the forestry sector to gross domestic product (GDP) was only 1\% while the eleventh five year plan (2007-2012) reported that forestry puts its contribution to GDP at $2.5 \%$ only. Undervaluation of forests in India is causing immense losses to the forestry sector and overall economic system. Forests have been accounted only for their tangible products and services which include direct cash exchange. The non-cash, intangible or indirect use values are required to be thoroughly accounted for total economic valuation of the forest sector. REDD+ is one such framework with the goal of creating an economic value of the standing forest through conservation, sustainable management and enhancing the forest carbon stocks. 


\section{International Journal of Science and Research (IJSR) \\ ISSN (Online): 2319-7064 \\ Index Copernicus Value (2013): 6.14 | Impact Factor (2014): 5.611}

Carbon management in forests is an important agenda of the first half of the 21 st century in India concerning greenhouse effect and mitigation of global climatic changes. The practices of restoration and rehabilitation of degraded forest land, agroforestry, regeneration, reforestation, afforestation, prevention of grazing on forest land and fire control are some of the viable carbon management options in Indian context. The CDM could provide an opportunity to secure funds to restore the region"s degraded forests and establish new areas of forest cover. The concept of Joint Forest Management based on principals of community or participatory forestry has gained a widespread significance in managing forests over the entire nation. As per the study of Balooni and Inoue [36], there are more than 84,000 JFM Committees spread over 27 states, managing about 17 million hectares (ha) of

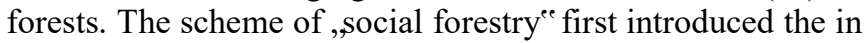
1976 by National Commission on Agriculture; Government of India can also make considerable differences in overall forest cover in a short time. More land under tree cover will ultimately play a significant role in sequestering the atmospheric $\mathrm{CO}_{2}$ in biomass and soil and thus contribute in mitigation of climate change [37].

Thus, in a developing country like India, mitigation options such as improved energy efficiency both in industrial and transport sector, encouragement for use of biomass energy as a substitute for fossil fuels, improved forest management and conservation including avoided deforestation, promoting forest regeneration, improving agricultural practices and incorporation of agroforestry systems can prove to be much more cost effective means of reducing atmospheric carbon.

\section{Conclusion}

Climate is a major determinant of both the composition and behavior of a region's ecosystem. It also influences the infrastructure and culture of human society residing within it. Hence, climate statistics are an important factor in ecosystem management and planning for socio-economic development. The international rules and institutions that regulate issues of climate change are diverse in terms of membership, context and time of creation and their effective implementation forming a loosely linked regime. It has been indicated that the impacts of climate change whether economic or social would be distributed unevenly across the globe. The large damage will be borne by several nations in tropics with little potential of benefits for some countries in temperate zone $[38,39]$. This uneven distribution further makes international coordination very crucial and at the same time very difficult to achieve.

The world is poised to invest an estimated \$16 trillion in energy infrastructure, with annual carbon dioxide emissions estimated to rise by 60 percent from 2003 until 2030 [40]. The only hope to tackle the problem of global warming resides in the change of human behavior and giving time to engineers to devise, develop, and deploy technological solutions [7]. The scale of the forest carbon markets have climbed to $75 \mathrm{MtCO}_{2} \mathrm{e}$, valued at an estimated $\$ 432$ million with projects impacting more than 7.9 million hectares in 49 countries from every region of the world [41]. REDD+ mechanism will also need to be integrated with forest governance reform processes as this has the potential to increase the value of forest through a system of payments with respect to their potential to capture and sequester carbon. The carbon sequestration potential of tree plantations also plays a significant role in stabilizing the concentration of atmospheric greenhouse gases and thus mitigating climate change [42].

Climate change is politically a difficult problem for three fundamental reasons. First, it is a global problem; second, it is an intergenerational problem as the negative effects are to be borne by future generations and third the adaptation measures require changing habits of billions of people while practical policies to generate incentives for these behavioral changes require action by governments that may not exert any influence on their subjects [43].

In complexity of climate change concept, UNFCCC and IPCC will continue to play an umbrella role providing climate change projections, information, legal standards, comprehensive policy measures and constituting forum for negotiation at a single platform. All international, national and regional measures and efforts are needed to be integrated with each other to reduce the GHG emissions and stabilize atmospheric $\mathrm{CO}_{2}$ concentration. The costs of action now are smaller than the costs of action in the near future after things worsen. Therefore, to be more effective in fighting against climate change, an early start is more important than having strong incentive at a later stage.

\section{References}

[1] IPCC: "Summary for Policymakers", in: Climate Change 2007: The Physical Science Basis. Contribution of Working Group I to the Fourth Assessment Report of the Intergovernmental Panel on Climate Change, Solomon, S., D. Qin, M. Manning, Z. Chen, M. Marquis, K.B. Averyt, M. Tignor and H.L. Miller (eds.), Cambridge University Press, Cambridge, United Kingdom and New York, NY, USA, 2007.

[2] IPCC: "Summary for Policymakers", in: Climate Change 2013: The Physical Science Basis. Contribution of Working Group I to the Fifth Assessment Report of the Intergovernmental Panel on Climate Change, Stocker, T.F., D. Qin, G.-K. Plattner, M. Tignor, S. K. Allen, J. Boschung, A. Nauels, Y. Xia, V. Bex and P.M. Midgley (eds.), Cambridge University Press, Cambridge, United Kingdom and New York, NY, USA, 2013.

[3] IPCC: "Summary for Policymakers", in: Managing the Risks of Extreme Events and Disasters to Advance Climate Change Adaptation, Field, C.B., V. Barros, T.F. Stocker, D. Qin, D.J. Dokken, K.L. Ebi, M.D. Mastrandrea, K.J. Mach, G.-K. Plattner, S.K. Allen, M. Tignor and P.M. Midgley (eds.), A Special Report of Working Groups I and II of the Intergovernmental Panel on Climate Change. Cambridge University Press, Cambridge, United Kingdom and New York, NY, USA, 2012

[4] D. Archer, and V. Brovkin, "Millennial atmospheric lifetime of anthropogenic $\mathrm{CO}_{2}$ ", Climatic Change, 90(3) pp. 283-297, 2008

[5] MoEF (Ministry of Environment and Forest), "Climate Change and India: Towards preparation of 


\section{International Journal of Science and Research (IJSR) \\ ISSN (Online): 2319-7064}

Index Copernicus Value (2013): 6.14 | Impact Factor (2014): 5.611

comprehensive climate change assessment". Print Process. MoEF, Government of India, 2009

[6] Y. Malhi, D. D. Baldocchi, and P.G. Jarvis, "The carbon balance of tropical, temperate and boreal forests", Plant, Cell and Environment 22, pp. 715-740, 1999.

[7] L.G. Thompson, "Climate Change: The Evidence and Our Options”, The Behavior Analyst, 33 (2), pp. 153 $170,2010$.

[8] S. Meijer, and R. Damania, "Carbon finance and the forest sector in northeast India", Background Paper No. 11 for "Development and Growth in Northeast India: The Natural Resources, Water, and Environment Nexus". World Bank, Washington. D.C, 2006.

[9] T. Pearson, S. Walker, and S. Brown, "Guidebook for the formulation of Afforestation and Reforestation Projects under Clean Development Mechanism", International Tropical Timber Organization, Technical Series, 25, 2006.

[10] L.K. Price, and A.T. McKane, "Policies and Measures to realise Industrial Energy Efficiency and mitigate Climate Change", UN Energy-Energy Efficiency Cluster, 2009.

[11]IPCC: "Mitigation of Climate Change", Contribution of Working Group III to the Fourth Assessment Report of the Intergovernmental Panel on Climate Change, Cambridge University Press, Cambridge, UK, 2007.

[12]FAO (Food and Agriculture Organization), "Woodfuels and climate change mitigation: case studies from Brazil, India and Mexico", Forests and climate change, Working Paper 6.F, 2010.

[13]N. Stern, "Stern Review: The economics of climate change", Her Majesty"s Treasury, London, UK, 2006.

[14]A. Angelsen, and S. Wertz-Kanounnikoff, "What are key design issues for REDD and the criteria for assessing options?", in Moving Ahead with REDD: Issues, Options and Implications, A. Angelsen (ed.), Center for International Forestry Research (CIFOR), Bogor, Indonesia, 2008.

[15]C. Boisvenue, and S.W. Running, "Impacts of climate change on natural forest productivity evidence since the middle of the 20th century", Global Change Biology 12 (5), pp. 862-882, 2006.

[16] A. Fischlin, G.F. Midgley, J.T. Price, R. Leemans, B. Gopal, C. Turley, M.D.A. Rounsevell, O.P. Dube, J. Tarazona, and A.A. Velichko, "Ecosystems, their properties, goods, and services. climate change 2007: Impacts, adaptation and vulnerability", in Contribution of working group II to the fourth assessment report of the Intergovernmental Panel on Climate Change, Parry, M.L., Canziani, O.F., Palutikof, J.P., Van Der Linden, P.J. Hanson,C.E. (ed.), Cambridge University Press, Cambridge, UK, 2007.

[17]H-H. Rogner, D. Zhou, R. Bradley, P. Crabbé, O. Edenhofer, B. Hare, L. Kuijpers, and M. Yamaguchi, "Introduction" in Climate Change 2007: Mitigation, Contribution of Working Group III to the Fourth Assessment Report of the Intergovernmental Panel on Climate Change, Metz, B., O.R. Davidson, P.R. Bosch, R. Dave and L.A. Meyer (eds), Cambridge University Press, Cambridge, UK and New York, NY, USA, 2007.

[18]FAO (Food and Agriculture Organization), "Global Forest Resources Assessment 2005: Progress towards sustainable forest management”, FAO Forestry Paper 147, Rome, 2006.

[19]IPCC, "Summary for Policymakers", in: Climate Change 2007: mitigation. Contribution of Working Group III to the Fourth Assessment Report of the Intergoevrnmental Panel on Climate Change, B. Mertz, O.R. Davidson, P.R. Bosch, R. Dave, L.A. Meyer (eds), Cambridge, UK and New York, NY: Cambridge University Press, 2007.

[20] K.R. Richards, and C. Stokes, "A Review of Forest Carbon Sequestration Cost Studies: a Dozen Years of Research." Climatic Change, 63(1), pp. 1-48, 2004.

[21]B. Sohngen, A. Golub, and T. Hertel, "The Role of Forestry in Carbon Sequestration in General Equilibrium Models", in: Economic Analysis of Land Use in Global Climate Change Policy, T. Hertel, S. Rose, R. Tol. (eds.), New York, Routledge, 2009.

[22]D. Reed, "Economic and societal benefits of soil carbon management: policy implication and recommendation", in: Soil Carbon Management:Economic, Environmental and Societal Benefits, J. Kimble, C.W. Rice, D. Reed, S. Mooney, R. F. Follete and R. Lal (eds.), CRC Press, Taylor and Francis Group, USA. Pp. 13-43, 2007.

[23] K. Hamilton, U. Chokkalingam, and M. Bendana, "State of the Forest Carbon Markets 2009: Taking Root \& Branching Out", Ecosystem Market Place. Forest Trends, 2010.

[24] S.M. Limaei, "Risk management in forestry; Economics perspectives", 3rd International Conference on Advanced Management Science. IPEDR vol.(19) IACSIT Press, Singapore, 2011

[25] J.N. Hool, "A dynamic programming- Markov chain approach to forest production control", Forest Science, Monograph 12, 1966.

[26]IPCC: "Summary for Policy Makers" in: Climate Change 2007: Climate Change Impacts, Adaptation and Vulnerability. Inter-Governmental Panel on Climate Change, 2007.

[27] R. Rasool, S.S. Kukal, and G.S. Hira, "Soil organic carbon and physical properties as affected by long-term application of FYM and inorganic fertilizers in maizewheat system", Soil \& Tillage Research, 101, pp. 31-36, 2008.

[28]FAO (Food and Agriculture Organization), "Managing forests for climate change, FAO working with countries to tackle climate change through sustainable forest management", I1960E/1/11.10, 2010.

[29]P. Patosaari, "Forest and Climate Change: mitigation and adaptation through sustainable forest management", in: 60th Annual DPI / NGO Conference on Climate Change: How it Impacts Us All, Roundtable on Coping with Climate Change: Best Land Use Practices United Nations, New York, 6 September 2007.

[30] Planning Commission, Government of India, "The Final Report of the Expert Group on Low Carbon Strategies for Inclusive Growth ${ }^{\text {ee }}, 2014$.

[31] World Bank, "India's Water Economy: Bracing for a Turbulent Future", India Water Strategy, World Bank, Washington, D.C., 2005

[32] Planning Commission, Government of India, "Twelfth Five Year Plan (2012-2017), Faster, More Inclusive and Sustainable Growth", Volume 1, 2012. 


\section{International Journal of Science and Research (IJSR) \\ ISSN (Online): 2319-7064}

Index Copernicus Value (2013): 6.14 | Impact Factor (2014): 5.611

[33] H. Fekete, F. Mersmann, and M. View, "Climate change mitigation in emerging economies: From potentials to actions", German Federal Environment Agency, 2013.

[34] Infrastructure Development Finance Company Ltd., "Draft: Barriers to development of renewable energy in India \& proposed recommendations", 2010..

[35] Council on Energy, Environment and Water, "Laying the Foundation for a Bright Future. Assessing Progress under Phase 1 of India's Solar Mission”, 2012.

[36] K. Balooni, and M. Inoue, "Joint Forest Management in India: The management change process", IMB Management Review, 2009.

[37]P. Arora, and S. Chaudhry, "Carbon Sequestration Potential of Populus deltoides plantation under Social Forestry Scheme in Kurukshetra, Haryana in Northern India" Journal of Materials and Environmental Science, 6 (3), pp. 703-720, 2015.

[38]R.S.J. Tol, "The marginal damage costs of carbon dioxide emissions: an assessment of the uncertainities", Energy Policy, 33, pp. 2064-2074, 2005.

[39]R. Mendelsohn, "Assessing the mark damages from climate change", in: Global Climate Change: The Science, Economics and Politics. Cheltenham, UK: Edward Elgar, 2003.

[40] L.H. Goulder, and W.A. Pizer, "The Economics of Climate Change", NBER Working Paper No. 11923, 2006.

[41]D. Diaz, K. Hamilton, and E. Johnson, "State of the Forest Carbon Markets 2011: From Canopy to Currency", Forest Trends, 2011.

[42] P. Arora, and S. Chaudhry, "Carbon Sequestration in Tree Plantations at Kurukshetra in Northern India", American International Journal of Research in Formal, Applied \& Natural Sciences, 5 (1), pp. 65-70, 2014.

[43] R.O. Keohane, and D.G. Victor, "The regime complex for climate change", Discussion paper for The Harvard Project on International Climate Agreement, pp. 10-33, 2010

\section{Author Profile}

Dr. Pooja Arora is working as an Assistant Professor in Institute of Environmental Studies, Kurukshetra University, Kurukshetra, India. She received her M.Sc. degree in 2008 and Ph. D. degree in 2015 in the subject of Environmental Sciences under the guidance of Prof. Smita Chaudhry from the same Department. She has worked on the carbon sequestration of various tree plantations at Kurukshetra. She has 3 years of teaching experience.

Prof. Smita Chaudhry is Director, Institute of Environmental Studies, Kurukshetra University, Kurukshetra, India. She received her Ph.D. degreein 1991(Ecology, Kumaun University, Nainital) and M.Sc. in 1984 (Botany, Kumaun University, Nainital). Her specializations are in Plant Ecology, Ecological Restoration and Environmental Biotechnology. She has 28 years of research \& teaching experience. 